Article

\title{
Investigation of the Influence of Aging on the Lubricity of Metalworking Fluids by Means of Design of Experiment
}

\author{
Benedikt Seidel ${ }^{1,2, *(\mathbb{D})}$ and Daniel Meyer ${ }^{1,2}$ (D) \\ 1 Leibniz Institute for Materials Engineering IWT, Badgasteiner Straße 3, 28359 Bremen, Germany; \\ dmeyer@iwt-bremen.de \\ 2 University of Bremen and MAPEX Center for Materials and Processes, Bibliothekstr. 1, 28359 Bremen, \\ Germany \\ * Correspondence: seidel@iwt-bremen.de; Tel.: +49-421-2185-1182
}

Received: 26 August 2019; Accepted: 1 October 2019; Published: 23 October 2019

\begin{abstract}
The influence of complex aging processes in water-miscible metalworking fluids on process performance is of high relevance for the metalworking industry. Because of the highly dynamic interactions in the complex "metalworking fluid" ecosystem, a distinct correlation between the aging process and the performance of the fluid in metalworking processes is hardly possible. Consequences of the aging process on physical, chemical, and biological properties of the fluid include aspects such as the decrease of the $\mathrm{pH}$ value, the increase of the droplet size in emulsions, the presence of bacterial cells, or the modification of the metalworking fluid composition. In the presented work, the influences of these aging aspects on the lubricity of metalworking fluids were investigated individually. A test series has been carried out, which was planned with a design of experiments method, to investigate interactions between the aging aspects regarding lubricity. In addition, the results enabled the development of an empirical regression model, which allowed an integrated description of the influence of the relevant aging aspects.
\end{abstract}

Keywords: aging aspects of metalworking fluid; correlation of aging aspects; design of experiments

\section{Introduction}

Metalworking fluids take an important part in a wide range of metalworking processes in modern industry, such as forming, milling, turning, and especially grinding. Its lubrication ability leads to reduced loads for tools, workpieces, and machine tools and decreases the necessary cutting power [1]. According to the German Standard DIN 51385, metalworking fluids are subdivided into "water-miscible" and "non-water-miscible" metalworking fluids. While non-water-miscible metalworking fluids are made of $100 \%$ oil and nonpolar additives, water-miscible metalworking fluids usually contain about $90 \%-95 \%$ water [2] and 5\%-10\% oil and additives, which are dissolved in the water or form an emulsion dispersed by surface-active agents. Because of the high thermal conductivity of water, the thermal loads of tools and workpieces can be reduced by an efficient dissipation of heat from the contact zone [1]. Beside lubrication, the removal of chips and grinding swarf corrosion, inhibition, long term stability, wettability, and low risk or no risk to workers and the environment are further relevant requirements. There is a wide range of additives to customize the properties to specific needs, such as biocidal, antiwear (AW), extreme pressure (EP), antifoam, or emulsifying additives [3]. The individual composition of the fluid can have a considerable effect on the performance in the machining process [4].

Because of the present environmental conditions, metalworking fluid systems are an adequate habitat for microorganisms. Water and sufficient nutrients are available in the metalworking fluid 
system, and the temperature is constantly within a convenient sector. The microorganisms can utilize the wide range of chemical compounds in metalworking fluids almost entirely to cover their demand of carbon and energy [5]. An intense maintenance of the cooling lubricant is crucial for a long service life, whereby particular attention is given to the bacterial load. The colonization of metalworking fluids by microorganisms such as bacteria or fungi has been investigated since the 1940s and is still the subject of various research activities [6-11]. When the fluid has been colonized, microbial growth in metalworking fluids can neither be completely avoided nor is the initial state of the fluid composition recoverable. Within a few weeks, the microbial load of metalworking fluids can reach a level of $10^{7}$ (or more) colony-forming units per milliliter $[8,10]$. The standard method of avoiding bacterial load is the addition of biocidal products such as bactericides and fungicides [9]. The treatment with ultrasound, ozone, or UV radiation are further strategies [11]. All those methods reveal specific disadvantages, such as negative influence on emulsion properties, localized or selective impact, or they are harmful to health and the environment [1].

Simultaneous to a decreasing number of additives over time due to the metabolic activity of microorganisms, compounds of microbial origin are released continuously in the metalworking fluid, such as low-molecular metabolites, surface-active agents, or extracellular polymeric substances (EPSs). The changes taking place in the cooling lubricant are shown schematically in Figure 1. Other consequences of bacterial colonization are decreasing $\mathrm{pH}$ values, increasing droplet sizes [8], or mechanical problems in the metalworking fluid cycle due to clogging of filters, pumps, and so on, by biofilms [7]. Further changes in the metalworking fluid occur due to thermal decomposition of molecules and oxidation processes, which take place in non-water miscible fluids, too. The metalworking fluid is therefore continuously subject to a combination of chemical, physical and biological effects. Consequently, the metalworking fluid is subjected to modifications resulting from the aging process, which are partly irreversible [8].

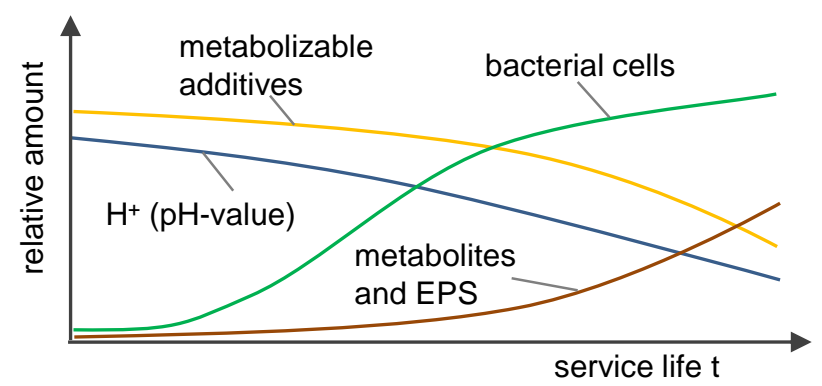

Figure 1. Schematic influence of biological colonization of water-miscible metalworking fluids. EPS, extracellular polymeric substance.

From a biological point of view, metalworking fluids are highly dynamic and complex ecosystems with a broad range of species. However, an aging-related quality loss of the metalworking fluid has not been verified scientifically so far. Various investigations (e.g., by Koch [12] and Grub et al. [13]) to evaluate metalworking fluid aging based on relevant parameters from the machining processes, such as machining forces, surface quality, or tool wear, have not allowed a clear description of the influence of aging on the performance of metalworking fluids. Also on the basis of tribological evaluation methods, long-term experiments showed no negative influence of aging on the lubricity of water-miscible metalworking fluids [10]. In industrial practice, regulatory limits are deduced from product requirements like low health hazard or corrosion protection, but not from the fluid's performance in the conducted metalworking process.

To evaluate the effects of the aging process on the performance of the fluid systematically, the individual influences of separated aspects of the aging process on the lubricity of the fluid have to be investigated individually. Separate evaluation of the individual aspects is of great relevance for the investigation of metalworking fluid aging. Regarding this, initial results have been presented by Seidel and Meyer, which are partly shown below [14]. However, in a metalworking fluid that is subjected 
to a natural aging process, the evaluated aspects do not occur isolated from each other. Therefore, the evaluation of interactions between the aspects is also of great relevance, which is described in this paper.

\section{Methodical Approach and Experimental Setup}

In this paper, an experimental program was developed and conducted that enabled a comprehensive analysis of the influence of aging processes on the lubricity of metalworking fluids. For this purpose, the design of experiments method was used. Besides the evaluation of interactions between the aspects, this approach also enabled the creation of an empirical regression model. The methodical approach of the presented work is schematically depicted in Figure 2.

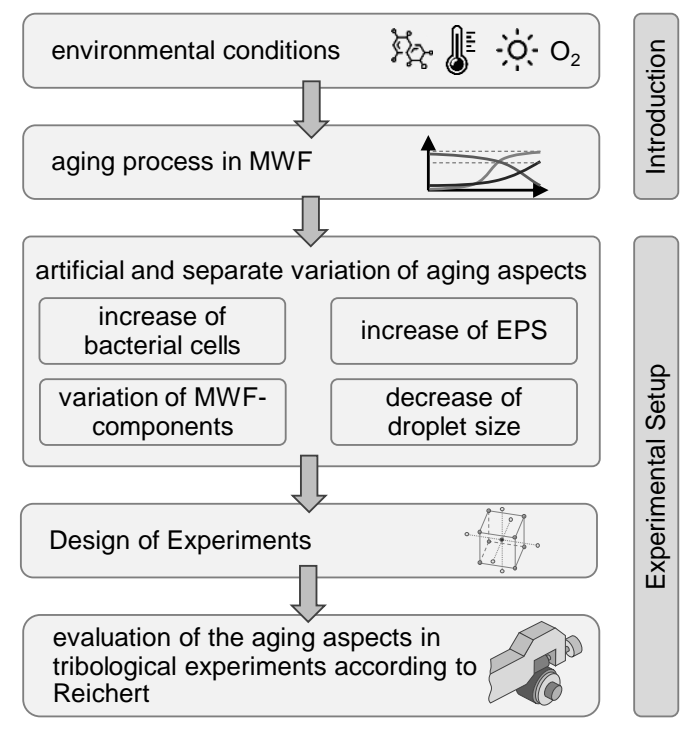

Figure 2. Methodical approach for the evaluation of metalworking fluid aging.

Design of experiments offers numerous methods and strategies for reducing the number of required experiments and making the use of resources (personnel, equipment, and time) more efficient while keeping the loss of quality of the information obtained as limited as possible. In this work, an experimental design in the so-called central composite design was created. Figure 3 shows a graphical illustration of such an experimental design for three input variables: $x_{1}, x_{2}$, and $x_{3}$. Each axis of the depicted cube represents an input parameter. Each point in the figure represents a specific combination of the three parameters. The eight cube points, the central points, and six star points outside the cube were used as parameter combinations in the experiments. Thus, with only 15 experiments this design of experiment can examine the relevance of three input parameters at five stages. Although it can no longer be visualized graphically, the central composition design can be used for any number of input parameters.

Various software programs are available to solve complex mathematical evaluations. In this work the commercial software Minitab was used. Experimental data will be transferred into an empirical model, which describes the outcome as a function of the input parameters $x_{1}, x_{2}, \ldots, x_{k}$.

$$
y=f\left(x_{1}, x_{1}, \ldots, x_{k}\right) .
$$

The influences of the varied input parameters are described with linear coefficients $b_{L}$ and square coefficients $b_{\mathrm{Q}}$. Additionally, interactions between input parameters are described by pursuant coefficients $b_{K}$. The constant part of the outcome parameter is represented by the coefficient $b_{c}$.

$$
\mathrm{y}=\mathrm{b}_{\mathrm{C}}+\mathrm{b}_{\mathrm{L} 1} \cdot \mathrm{x}_{1}+\mathrm{b}_{\mathrm{Q} 1} \cdot \mathrm{x}_{1}{ }^{2}+\mathrm{b}_{\mathrm{L} 2} \cdot \mathrm{x}_{2}+\mathrm{b}_{\mathrm{Q} 2} \cdot \mathrm{x}_{2}{ }^{2}+\ldots+\mathrm{b}_{\mathrm{K} 1} \cdot \mathrm{x}_{1} \cdot \mathrm{x}_{2}+\ldots
$$




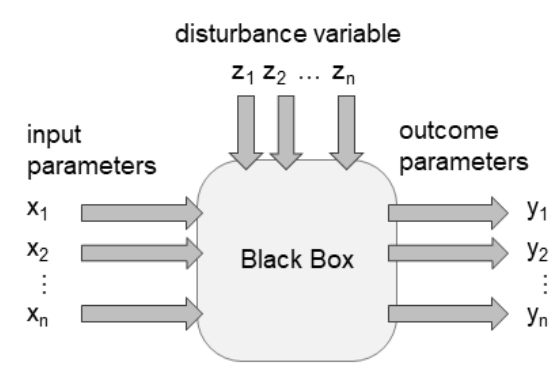

experimental design

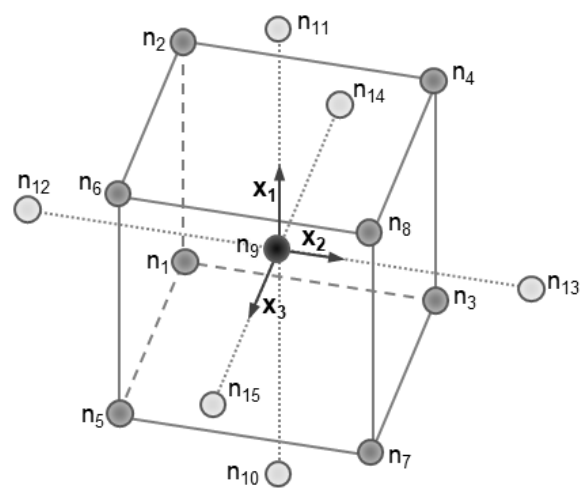

\begin{tabular}{cccccccccccccccc}
\hline No. & $\mathrm{n}_{1}$ & $\mathrm{n}_{2}$ & $\mathrm{n}_{3}$ & $\mathrm{n}_{4}$ & $\mathrm{n}_{5}$ & $\mathrm{n}_{6}$ & $\mathrm{n}_{7}$ & $\mathrm{n}_{8}$ & $\mathrm{n}_{9}$ & $\mathrm{n}_{10}$ & $\mathrm{n}_{11}$ & $\mathrm{n}_{12}$ & $\mathrm{n}_{13}$ & $\mathrm{n}_{14}$ & $\mathrm{n}_{15}$ \\
\hline $\mathrm{x}_{1}$ & - & + & - & + & - & + & - & + & 0 & -- & ++ & 0 & 0 & 0 & 0 \\
$\mathrm{x}_{2}$ & - & - & + & + & - & - & + & + & 0 & 0 & 0 & -- & ++ & 0 & 0 \\
$\mathrm{x}_{3}$ & - & - & - & - & + & + & + & + & 0 & 0 & 0 & 0 & 0 & -- & ++ \\
\hline
\end{tabular}

Figure 3. Top left: a black box view of an experiment according to [15]. Top right: graphical illustration of a central composite design (CCD) according to [16]. Bottom: the variation of the input parameters $\mathrm{x}_{1}, \mathrm{x}_{2}$, and $\mathrm{x}_{3}$ listed in tabular form.

This evaluation allows a mathematical description of the analyzed input parameters and an analysis of the interactions between the input parameters relating to the outcome parameter. With the calculation of different statistic parameters, it is possible to receive information about the developed model concerning accuracy, significance, and reliability.

To consistently measure the influence of different aging aspects on the lubricity, experiments were conducted with an individually adjustable model emulsion based on mineral hydrocrack oil. The components were available separately and, thus, enabled individual adjustments and defined the variation of the fluid composition. To vary the investigated aging aspects defined and allow reproducibility, artificial model substances have been applied.

For evaluating the lubricating abilities of the analyzed metalworking fluid samples, the tribology test according to Reichert has been engaged, since this test is very appropriate for the measurement of low-viscosity fluids such as water-miscible lubricants. The employed tribological system of the Reichert test consists of a cylindrical test specimen and a friction roller (both standard components of rolling bearings), which are crossed at an angle of $90^{\circ}$ (Figure 4). The test specimens are pressed against the friction roller at a constant load of $\mathrm{F}=300 \mathrm{~N}$, while the friction roller is immersed in the investigated fluid. In the experiment, the friction roller rotates for a duration of $57 \mathrm{~s}$ with a peripheral speed of $1.67 \mathrm{~m} / \mathrm{s}$, supplying a continuous contact zone with the test fluid. The size of the resulting worn area on the test specimen is the central benchmark of the Reichert tribology test, and it is used as a benchmark for the lubricating ability of the examined fluid. The lower the worn area, the higher the lubricating ability. The term "lubrication" is used here as a general term for the property of reducing friction and wear. This includes the separation of the friction partners by a lubricating film, which is particularly relevant in the range of low tribological loads, as well as the avoidance of wear through the effect of $\mathrm{EP} / \mathrm{AW}$ additives by adsorption of molecules on the metal surface, which is of importance in the range of higher tribological loads. 


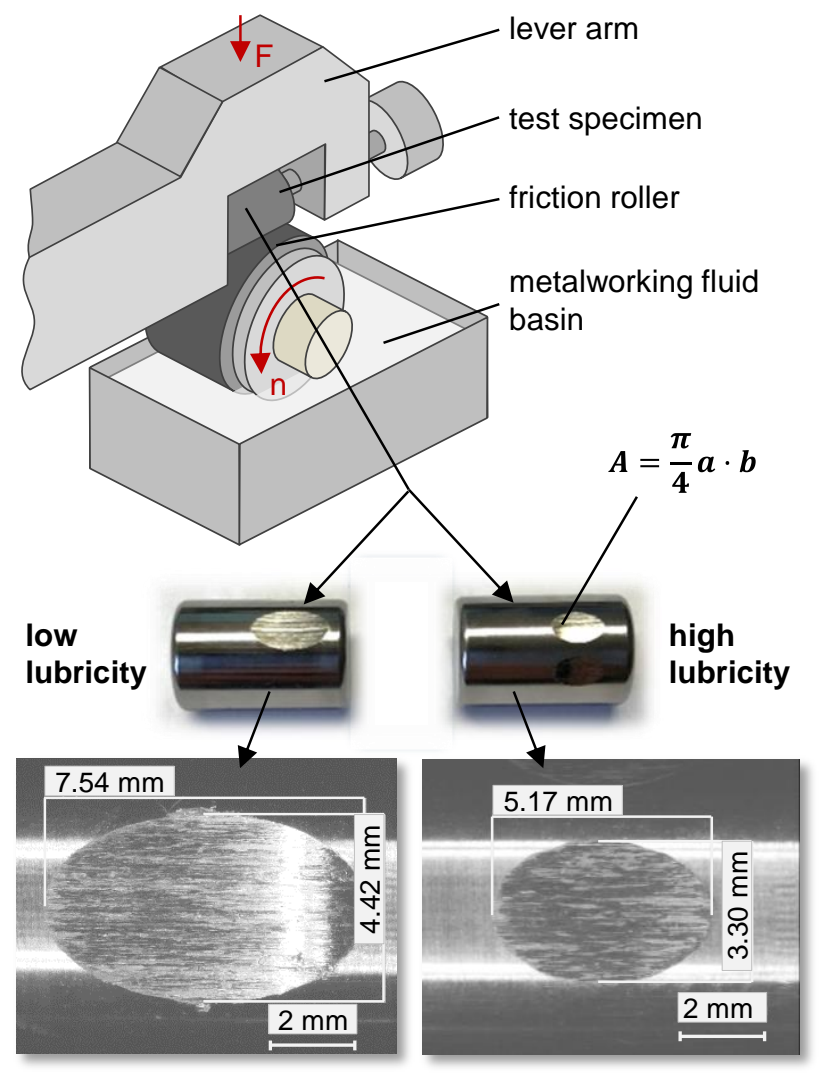

test: Reichert tribology test

test specimen: RC-12x18C, AISI 52100/ 100Cr6, height: $18 \mathrm{~mm}$, diameter: $12 \mathrm{~mm}$, hardness: $59.5 \pm 0.3 \mathrm{HRC}$ friction roller: IR 30x35x16, AISI 52100/ 100Cr6, diameter: $35 \mathrm{~mm}$, width: $16 \mathrm{~mm}$, hardness: $62.7 \pm 0.3 \mathrm{HRC}$

tribosystem: test specimen and friction roller, orthogonal orientated, friction roller immersed in metalworking fluid load: $F_{N}=300 \mathrm{~N}$ peripheral speed: $v=1.67 \mathrm{~m} / \mathrm{s}\left(\mathrm{n}=980 \mathrm{~min}^{-1}\right)$ test duration: $\mathrm{t}=57 \mathrm{~s}$

characteristic value: wear area $A$ on test specimen

Figure 4. Specifications of the Reichert tribology test.

An increase in lubricity is accompanied by a reduction in the coefficient of friction, which reduces the energy consumption in the manufacturing processes, for example. The variation of the coefficient of friction was also monitored in the tests. In a guideline of the German User Circle Industrial Lubricants (Ger. VKIS), the procedure of the Reichert test and the specific test parameters are described in detail [17]. Each combination of aspects in this design of experiment was repeated three times. The central point was repeated nine times due to its high relevance.

\section{Results and Discussion}

The selection of the investigated aging aspects is summarized in Table 1. They were varied artificially to be evaluated separately from each other. The minimum and maximum of the variation spectrum were derived from values described in available literature. The chosen aspects reveal the highest relevance for metalworking processes but do not represent all possible changes that may occur in natural aging processes. 
Table 1. Overview of the investigated aging aspects and information on the implementation and variation.

\begin{tabular}{|c|c|c|c|}
\hline Aging Aspect & Variation Spectrum & Model/Adjustment System & References \\
\hline droplet size & $\mathrm{d}_{\mathrm{m}}=2.25 \% \ldots 3.5 \%$ & concentration emulsifier & {$[8,18]$} \\
\hline bacterial cell bodies & $\mathrm{c}_{\mathrm{CB}}=10^{3} \ldots 10^{9} \mathrm{~mL}^{-1}$ & $\begin{array}{l}\text { spherical particles of PMMA } \\
\qquad(\mathrm{d}=1.5 \mu \mathrm{m})\end{array}$ & [5-10] \\
\hline $\begin{array}{l}\text { extracellular polymeric } \\
\text { substances (EPSs) }\end{array}$ & $\mathrm{c}_{\mathrm{EPS}}=0.0 \ldots 4.0 \mathrm{mg} / \mathrm{mL}$ & $\begin{array}{l}\text { mixture of } 1 / 3 \text { proteins and } 2 / 3 \\
\text { polysaccharides }\end{array}$ & {$[5,9,19]$} \\
\hline variation of antiwear additive & $\begin{array}{l}\mathrm{c}_{P S}=0 \% \ldots 10 \% \\
\text { (in concentrate) }\end{array}$ & variation of polysulfide (PS) & {$[3,5,8]$} \\
\hline
\end{tabular}

The selected aspects, the boundaries of the examined parameter variations, and the effect of a higher concentration on the worn area A are summarized in Figure 5 according to [14]. The appearance of cell bodies is a consequence of the aging processes in water-miscible metalworking fluids. With the accumulation of cell bodies, the lubricity of the fluid also increases. There is no loss of quality with an increasing amount of cell bodies. Therefore, future monitoring and maintenance strategies for metal working fluid should focus on the fluid composition and a homogenous concentration rather than on the prevention of bacterial colonization. Because of the deterioration of emulsifying components in the metalworking fluid by microorganisms, the droplet size increases. In the experiments, the emulsifier concentration varied between $2.25 \%$ and $3.5 \%$. A decreasing emulsifier concentration leads to a decline in the lubrication ability, as the results showed. The smaller the droplet size, the better the droplets can reach the contact zone between the friction partners [14].
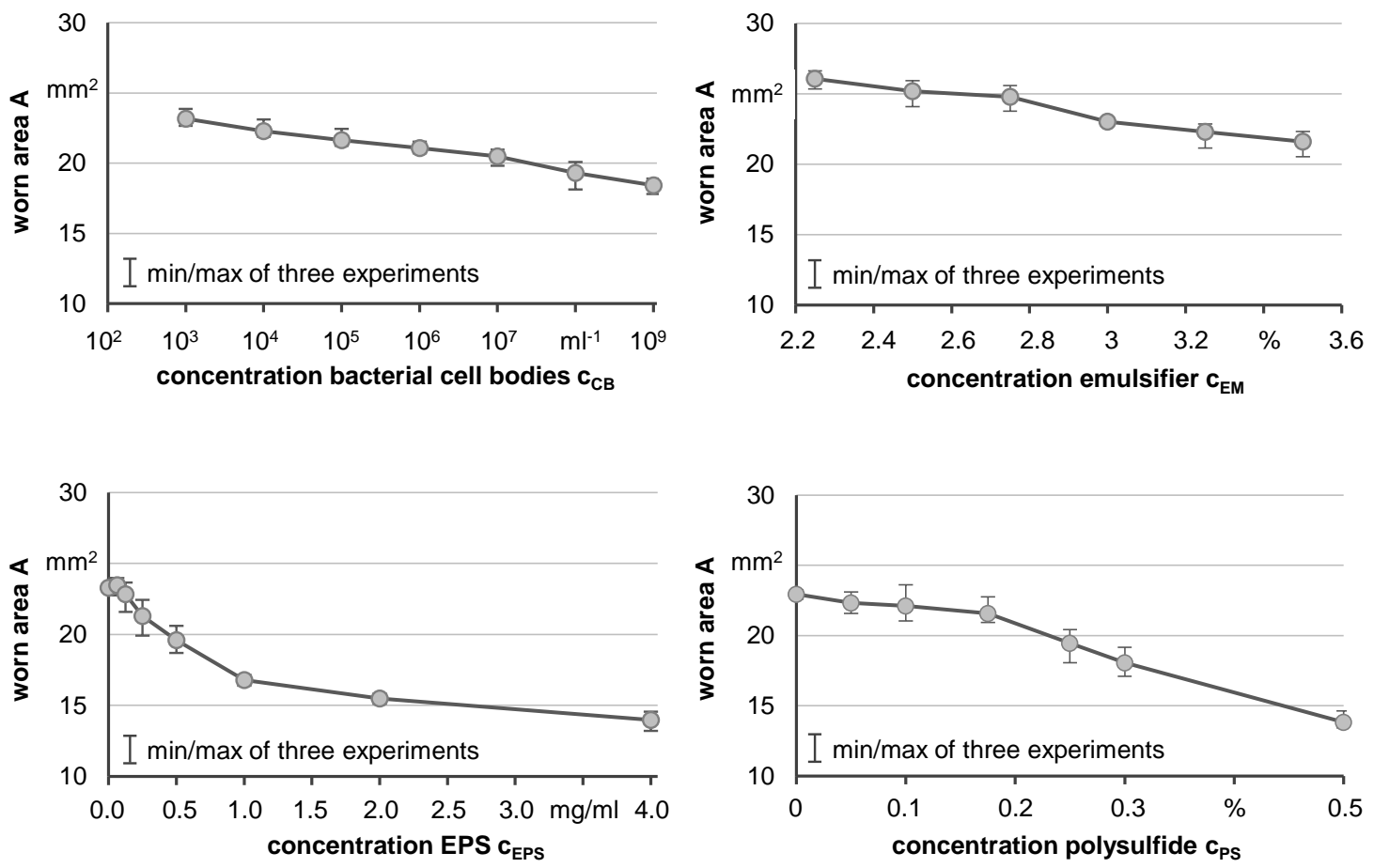

\begin{tabular}{|llll|}
\hline $\begin{array}{l}\text { evaluation method: } \\
\text { Reichert tribology test }\end{array}$ & $\frac{\text { test specimen }+}{\text { friction roller: }}$ & $\begin{array}{l}\text { test fluid: } \\
\text { model metalworkind fluid }\end{array}$ & $\frac{\text { measuring device: }}{\text { magnifier (8x) }}$ \\
test load, test duration: & 100Cr6 (AISI 52100) & $\begin{array}{l}\text { (hydrocrack oil + } \\
\text { emulsifier), } 5 \%, \mathrm{pH} 8.4\end{array}$ \\
\hline $300 \mathrm{~N}, 57 \mathrm{~s}$ & & & \\
\hline
\end{tabular}

Figure 5. Influence of separated aging aspects on lubricity according to [14]. 
Another aspect of the aging process of metalworking fluid is the presence of extracellular polymeric substances (EPSs). Typically, EPSs are built in biofilms in order to stabilize the film layer and provide further advantages such as the protection from hazardous environmental conditions or the storage of water. There exist a wide range of individual substances, mainly polysaccharides and proteins but also DNA and lipids. The results showed a significant increase of the lubricity with increasing concentration of EPSs in the metalworking fluid. With an increasing concentration of an antiwear additive, the lubricity of the model metalworking fluid increases as well [14]. In this work, the anti-wear additive polysulfide varied between $0 \%$ and $0.5 \%$. Separated evaluation of the aging aspects showed that the aspects influenced the lubricity and, thus, the performance of the model metalworking fluid.

Our methodology allowed the evaluation of each aspect separately, which is not possible in naturally aged samples because of the complexity of the aging process. However, systematic separation of the investigated aging aspects implies the limitation that possible interactions between the aspects are not investigated or taken into account. In order to achieve a complete picture of the aging aspects investigated and to analyze possible interactions between the aspects, a further evaluation of the aging aspects was carried out employing the central composite design, which is presented in the following paragraphs. Therefore, a completely new series of tests was designed and carried out, and the data received were evaluated statistically. The central innovation consisted of the systematic combination of the aspects to be investigated according to a concept developed with design of experiments. These investigations and the conclusions obtained from the generated data represent the scientific novelty of this work.

From the results of the tribological experiments, a first regression model was created with Minitab software. The first- and second-order terms (linear and quadratic) and the correlation coefficients were calculated, and their significance for the representation of the experimental results was estimated with adequate characteristic values. Table 2 summarizes all coefficients of the calculated model without further adjustments.

Table 2. Overview of the coefficients of the empirical model without further adjustments and with two coefficients of the variance analysis $(\mathrm{EM}=$ emulsifier, $\mathrm{CBs}=$ cell bodies, $\mathrm{EPSs}=$ extracellular polymeric substances, $\mathrm{PS}=$ polysulfide).

\begin{tabular}{|c|c|c|c|c|}
\hline Coefficient & Normalized Value & Input to the Model & $p$ Value & Removed Terms \\
\hline Model & & $94.50 \%$ & $0.0 \%$ & \\
\hline Linear & & $78.67 \%$ & & \\
\hline (emulsifier) & -0.080 & $0.16 \%$ & $16.5 \%$ & $(\mathrm{X})$ \\
\hline $\begin{array}{l}\text { (cell bodies) } \\
\text { (extracellular }\end{array}$ & -0.262 & $1.77 \%$ & $0.0 \%$ & \\
\hline $\begin{array}{l}\text { polymeric } \\
\text { substances) }\end{array}$ & -1.238 & $39.51 \%$ & $0.0 \%$ & \\
\hline (polysulfide) & -1.201 & $37.23 \%$ & $0.0 \%$ & \\
\hline Square & & $0.84 \%$ & & \\
\hline $\mathrm{EM} \times \mathrm{EM}$ & 0.014 & $0.18 \%$ & $82.0 \%$ & $x$ \\
\hline $\mathrm{CB} \times \mathrm{CB}$ & -0.061 & $0.00 \%$ & $31.9 \%$ & $x$ \\
\hline $\mathrm{EPS} \times \mathrm{EPS}$ & -0.101 & $0.06 \%$ & $9.8 \%$ & $x$ \\
\hline $\mathrm{PS} \times \mathrm{PS}$ & -0.161 & $0.60 \%$ & $0.9 \%$ & \\
\hline 2-factor interactions & & $15.00 \%$ & & \\
\hline $\mathrm{EM} \times \mathrm{CB}$ & 0.000 & $0.00 \%$ & $99.6 \%$ & $x$ \\
\hline $\mathrm{EM} \times \mathrm{EPS}$ & -0.032 & $0.02 \%$ & $64.3 \%$ & $X$ \\
\hline $\mathrm{EM} \times \mathrm{PS}$ & 0.002 & $0.00 \%$ & $98.3 \%$ & $x$ \\
\hline $\mathrm{CB} \times \mathrm{EPS}$ & 0.006 & $0.00 \%$ & $93.7 \%$ & $x$ \\
\hline $\mathrm{CB} \times \mathrm{PS}$ & 0.028 & $0.01 \%$ & $68.6 \%$ & $x$ \\
\hline $\mathrm{EPS} \times \mathrm{PS}$ & 0.933 & $14.97 \%$ & $0.0 \%$ & \\
\hline Error & & $5.50 \%$ & & \\
\hline Total & & $100.00 \%$ & & \\
\hline
\end{tabular}


The contribution to the model listed in the table indicates which percentage of the experimental values represented by the model can be attributed to the respective term. The larger this value, the more important it is for the model. The $p$ value is a benchmark for the probability that the "null hypothesis" is valid for the respective coefficient. The null hypothesis means that the model or coefficient does not represent the changes in the result variable. If the $p$ value is below $5 \%$, the term is considered sufficiently significant or reliable. With the help of these two parameters, the empirical model was simplified by deleting terms that were not sufficiently relevant. The excluded terms are marked in Table 2. Although the deletion of each term is accompanied by a loss of information, it can be estimated as acceptable on the basis of the determined parameters.

The new equation is:

$$
\mathrm{A}=\mathrm{b}_{0}+\mathrm{b}_{\mathrm{L}, \mathrm{EM}} \cdot \mathrm{c}_{\mathrm{EM}}+\mathrm{b}_{\mathrm{L}, \mathrm{CB}} \cdot \lg \left(\mathrm{c}_{\mathrm{CB}}\right)+\mathrm{b}_{\mathrm{L}, \mathrm{EPS}} \cdot \mathrm{c}_{\mathrm{EPS}}+\mathrm{b}_{\mathrm{L}, \mathrm{PS}} \cdot \mathrm{c}_{\mathrm{PS}}+\mathrm{b}_{\mathrm{Q}, \mathrm{PS}} \cdot \mathrm{c}_{\mathrm{PS}}{ }^{2}+\mathrm{b}_{\mathrm{K}} \cdot \mathrm{c}_{\mathrm{EPS}} \cdot \mathrm{c}_{\mathrm{PS}} \cdot
$$

By limiting the number of relevant terms, the number of coefficients could be significantly reduced from 15 to 7, which considerably simplified the handling of the model. Table 3 shows an overview of the parameters applied in the resulting model. The table summarizes the description, the scalar values, and, if applicable, the permitted intervals of the variables and coefficients contained in the model.

Table 3. Explanation of the coefficients and variables of the empirical model with the respective values or intervals.

\begin{tabular}{|c|c|c|c|c|}
\hline Parameter & Symbol & Coefficient/Variable & Value/Interval & Dimension \\
\hline Result & A & Variable & & $\mathrm{mm}^{2}$ \\
\hline Constant & $\mathrm{b}_{0}$ & Coefficient & 26.40 & $\mathrm{~mm}^{2}$ \\
\hline Concentration EM & $\mathrm{c}_{\mathrm{EM}}$ & Variable & $(2.25 \mid 3.5)$ & $\%$ \\
\hline Linear factor EM & $b_{L, E M}$ & Coefficient & -0.256 & $\mathrm{~mm}^{2} / \%$ \\
\hline Concentration $\mathrm{CB}$ & $\mathrm{C}_{\mathrm{CB}}$ & Variable & $\left(10^{4} \mid 10^{9}\right)$ & $\mathrm{mL}^{-1}$ \\
\hline Linear factor CB & $\mathrm{b}_{\mathrm{L}, \mathrm{CB}}$ & Coefficient & -0.2093 & $\mathrm{~mm}^{2}$ \\
\hline Concentration EPS & $c_{\text {EPS }}$ & Variable & $(0.0 \mid 2.0)$ & $\mathrm{mg} / \mathrm{mL}$ \\
\hline Linear factor EPS & $b_{L, E P S}$ & Coefficient & -5.907 & $\mathrm{~mm}^{2} \cdot \mathrm{mL} / \mathrm{mg}$ \\
\hline Concentration PS & $\mathrm{C}_{\mathrm{PS}}$ & Variable & $(0.0 \mid 0.5)$ & $\%$ \\
\hline Linear factor PS & $\mathrm{b}_{\mathrm{L}, \mathrm{PS}}$ & Coefficient & -19.02 & $\mathrm{~mm}^{2} / \%$ \\
\hline Square factor PS & $b_{Q, P S}$ & Coefficient & -8.43 & $\mathrm{~mm}^{2} / \%^{2}$ \\
\hline Correlation EPS|PS & $\mathrm{b}_{\mathrm{K}}$ & Coefficient & 11.21 & $\mathrm{~mm}^{2} \cdot \mathrm{mL} / \mathrm{mg}^{\circ}$ \\
\hline
\end{tabular}

After inserting the corresponding data in the general formula, for the empirical model, the following equation results:

$$
\begin{aligned}
\mathrm{A}= & 26.40 \mathrm{~mm}^{2}-0.256 \frac{\mathrm{mm}^{2}}{\%} \cdot \mathrm{c}_{\mathrm{EM}}-0.2093 \mathrm{~mm}^{2} \cdot \lg \left(\mathrm{c}_{\mathrm{CB}}\right)-5.907 \frac{\mathrm{mm}^{2} \cdot \mathrm{mL}}{\mathrm{mg}} . \\
& \mathrm{c}_{\mathrm{EPS}}-19.02 \frac{\mathrm{mm}^{2}}{\%} \cdot \mathrm{cPS}_{\mathrm{PS}}-8.43 \cdot \frac{\mathrm{mm}^{2}}{\%^{2}} \cdot \mathrm{c}_{\mathrm{PS}}{ }^{2}+11.21 \frac{\mathrm{mm}^{2} \cdot \mathrm{mL}}{\mathrm{mg} \%} \cdot \mathrm{c}_{\mathrm{EPS}} \cdot \mathrm{c}_{\mathrm{PS}} .
\end{aligned}
$$

Equation (4) shows that the influence of aging aspects can be described mainly by linear elements. Only the influence of the polysulfide concentration is additionally described by a second order term. Regarding the influence of the cell body concentration, it must be considered that the model determined a linear coefficient for the logarithm of the concentration. Therefore, there was no direct linear relationship. For the investigated interactions, only the coefficient for the interaction between polysulfide and EPS remained in the model.

Additionally, the table showed a low significance for the linear coefficient of the emulsifier. The probability that the null hypothesis was correct was $16.5 \%$ ( $p$ value). Although the term contributed a minor influence to the model, the probability that this term $\mathrm{b}_{\mathrm{L}, \mathrm{EM}}$ describes random variation of the outcome parameter than the actual effect of the emulsifier was bigger than the maximum $5 \%$. This is 
the reason for further simplification. The linear coefficient of the emulsifier was removed, which results in following equation:

$$
\begin{gathered}
\mathrm{A}=25.666 \mathrm{~mm}^{2}-0.2093 \mathrm{~mm}^{2} \cdot \lg \left(\mathrm{c}_{\mathrm{CB}}\right)-5.907 \frac{\mathrm{mm}^{2} \cdot \mathrm{mL}}{\mathrm{mg}} \cdot \mathrm{c}_{\mathrm{EPS}}-19.02 \frac{\mathrm{mm}^{2}}{\%} . \\
\mathrm{CPS}_{\mathrm{PS}}-8.43 \cdot \frac{\mathrm{mm}^{2}}{\%^{2}} \cdot \mathrm{CPS}^{2}+11.21 \frac{\mathrm{mm}^{2} \cdot \mathrm{mL}}{\mathrm{mg} \%} \cdot \mathrm{c}_{\mathrm{EPS}} \cdot \mathrm{c}_{\mathrm{PS}} .
\end{gathered}
$$

The percentage of variation of the outcome parameter explained by the revised model was $\mathrm{R}^{2}=93.97 \%$ ("contribution to the model"); thus, it was relatively high. The standard deviation of the resulting residuals (respective deviations of the model from the experimental values of the outcome parameter) was $\mathrm{S}=0.474 \mathrm{~mm}^{2}$. The range of variation of the outcome parameter (the worn area $\mathrm{A}$ in the tribology test) was significantly higher than the value of the standard variation $S$, and for this reason, the model can be described as reliable in a first approximation.

Because of the three variables in the model that describe the tribological area, a complete graphical depiction of the data is not possible. If the third input parameter is constant, the effect of two input parameters can be shown by a three-axle diagram. Figure 6 shows three diagrams, whereby each one displays the effect of two of the three investigated parameters to the tribological area.

The model confirmed the results of the tribological experiments, in which only one defined input parameter was varied at a time. The polysulfide and the EPS revealed a strong influence on lubricity. Thereby, the polysulfide concentration showed no linear correlation with the lubricity. Only with a higher concentration did the wear-reducing effect of the additive become clearly distinguishable from the lubricity of the model-cooling lubricant. Therefore, the model also contains a quadratic component that approximately describes this influence. The cell concentration also had an influence on the lubricity. However, it was not as strong as the influence of the additive polysulfide or the EPS.

The interaction term in the model takes two input parameters, polysulfide and EPS concentrations, into account and represents a saturation effect of the two components in combination. Both polysulfide and EPS had a strong influence on the lubricity. If they were combined, the resulting lubricity increased further but could not be described by the sum of the two individual influencing variables. This characteristic is described approximately by the interaction coefficient. This correlation is an interesting and a fundamentally new finding, which could be achieved through the use of design of experiment methods. This saturation effect can be attributed to the decreasing amount of available space on the metal surface. Both the surface-active biopolymers of EPS and the polysulfide reduce wear by adsorbing molecules on the metal surface. With increasing concentration, a further increase of the concentration as well as the combination with another "additive" becomes less and less effective as the molecules cannot find a place on the metal surface anymore.

In addition to the identification of an interaction between the two input variables of polysulfide and EPS concentrations, it is also important to note the absence of further interactions between other combinations of input variables.

Beside the resulting wear, the coefficient of friction is also a property of tribological systems with fundamental relevance. Therefore, in addition to the evaluation of the wear surface, the development of the coefficient of friction in the course of a test was evaluated on three exemplary samples (Figure 7). For a better comparability with the wear surface, the three examined metalworking fluid samples (A, B, and C) are also marked in Figure 6.

As can be seen in Figure 7, during the course of an experiment, the coefficient of friction basically changed between two levels. At the beginning of the experiment, there was a phase of high friction and consequently large material removal. After a certain time, the tribology system shifted into a sliding phase, in which the friction coefficient decreased significantly and the test ran very smoothly. The difference in tests with metalworking fluid samples of high and low lubricity is not the level of the coefficient of friction in the two phases but the time of the change from the high level to the low one. The better the lubricity of a metalworking fluid, the earlier the tribology system enters the sliding phase. If the mean value of the coefficient of friction is calculated over the entire test, it can be seen, 
as expected, that high wear correlates with a higher mean coefficient of friction. However, Figure 7 also clearly shows that the difference between the resulting mean coefficients of friction is less significant than the difference between the resulting wear surfaces.

Overall, the reliability of the developed empirically determined model should not be overestimated in terms of a quantitative prediction of the lubricity. All correlations and interactions are described quantitatively with precise coefficients (with any number of decimal places). But the resulting model is only as reliable as the experimental data on which it is based. For example, the values of the "corner points" of the area diagrams shown in Figure 6 were calculated by extrapolation, which naturally implies the possibility of considerable deviations that were not validated by experimental data. But in general, the established model is well qualified for a qualitative description of the influence of different aging aspects on the lubricity of the metalworking fluid than for the precise prediction of the expected lubricity at any (usually unknown) composition of the lubricant.
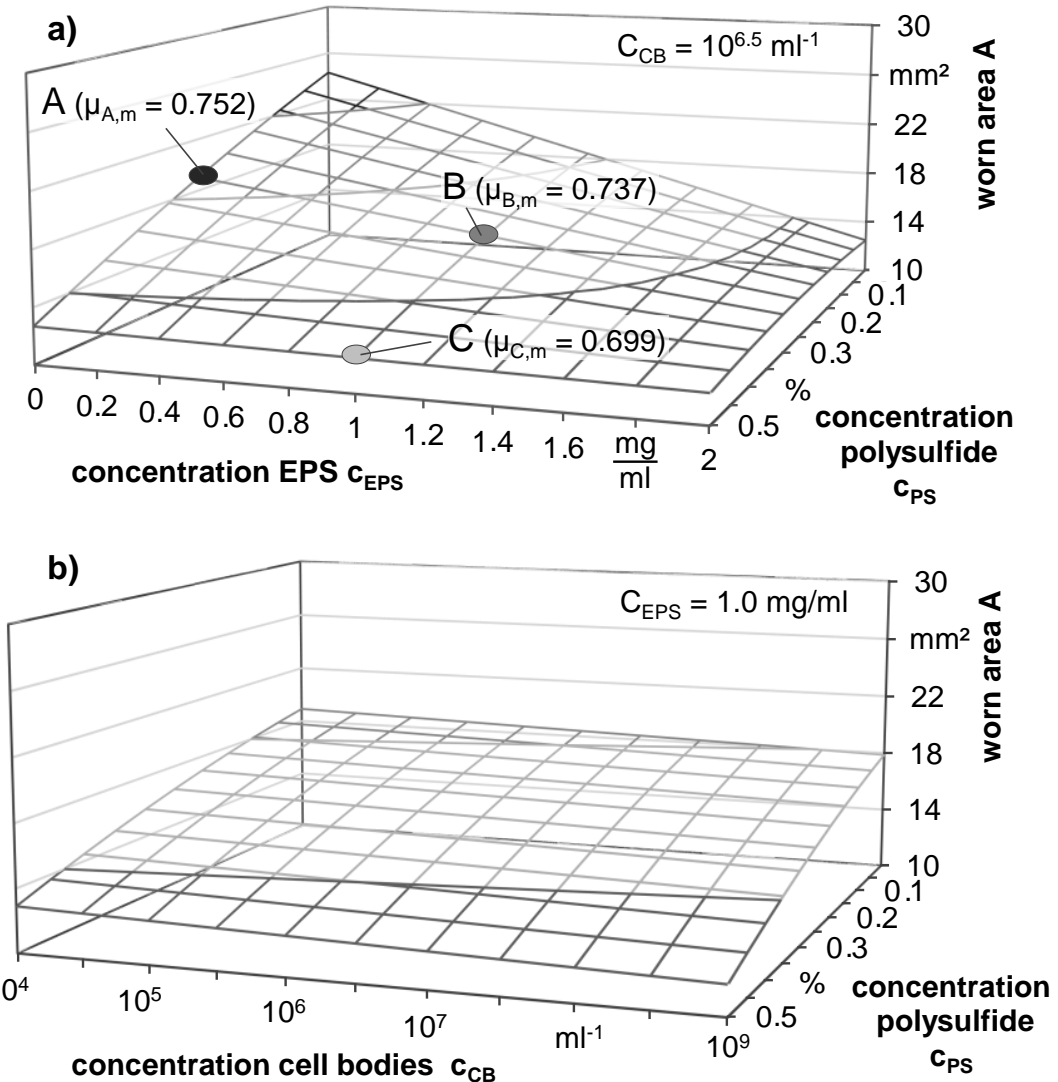

$$
\text { c) }
$$

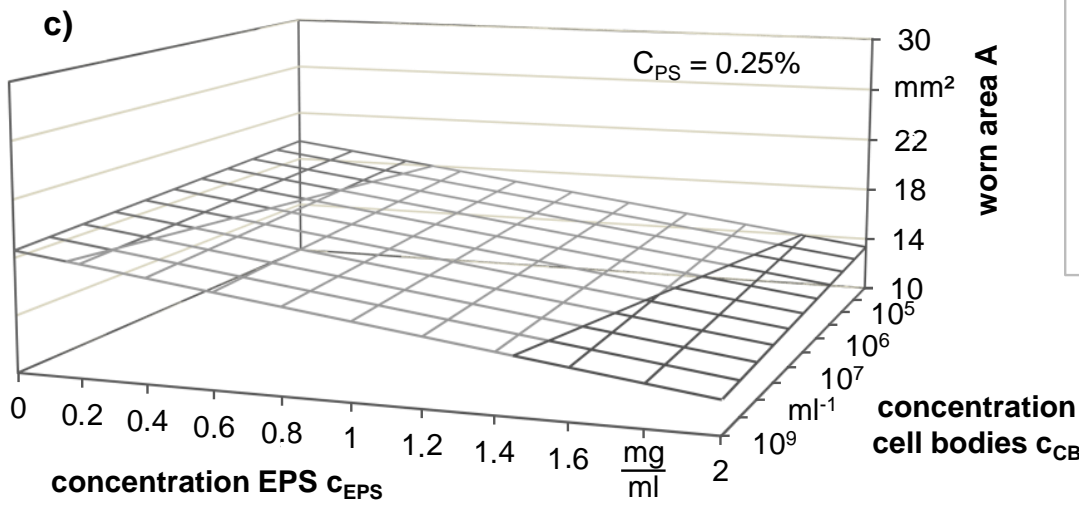

Evaluation method:

Reichert tribology test

Test specimen:

$100 \mathrm{Cr} 6$

Test force/ speed:

$300 \mathrm{~N} / 950 \mathrm{~min}^{-1}$

Test duration:

$60 \mathrm{~s}$

Test medium:

Model emulsion, $5 \%$

Outcome:

Worn area

Varied input parameters:

Concentration of

polysulfide $\mathrm{C}_{\mathrm{PS}}$

cell bodies $\mathrm{C}_{\mathrm{CB}}$,

EPS C $C_{\text {EPS }}$

Repetitions:

3 (central point: 9)

Regression model:

Design of Experiment:

Central-Composite-Design

Standard deviation:

$\mathrm{S}=0.474 \mathrm{~mm}^{2}$

Amount of variation

explained by the model:

$R^{2}=93.97 \%$

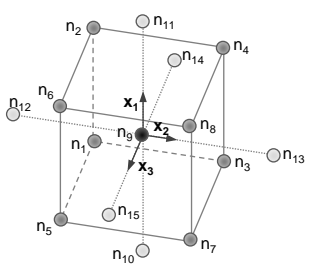

Figure 6. Empirical visualization of the influence of the aging aspects on the lubricity of the model metalworking fluid. In each figure, one coefficient is constant. 


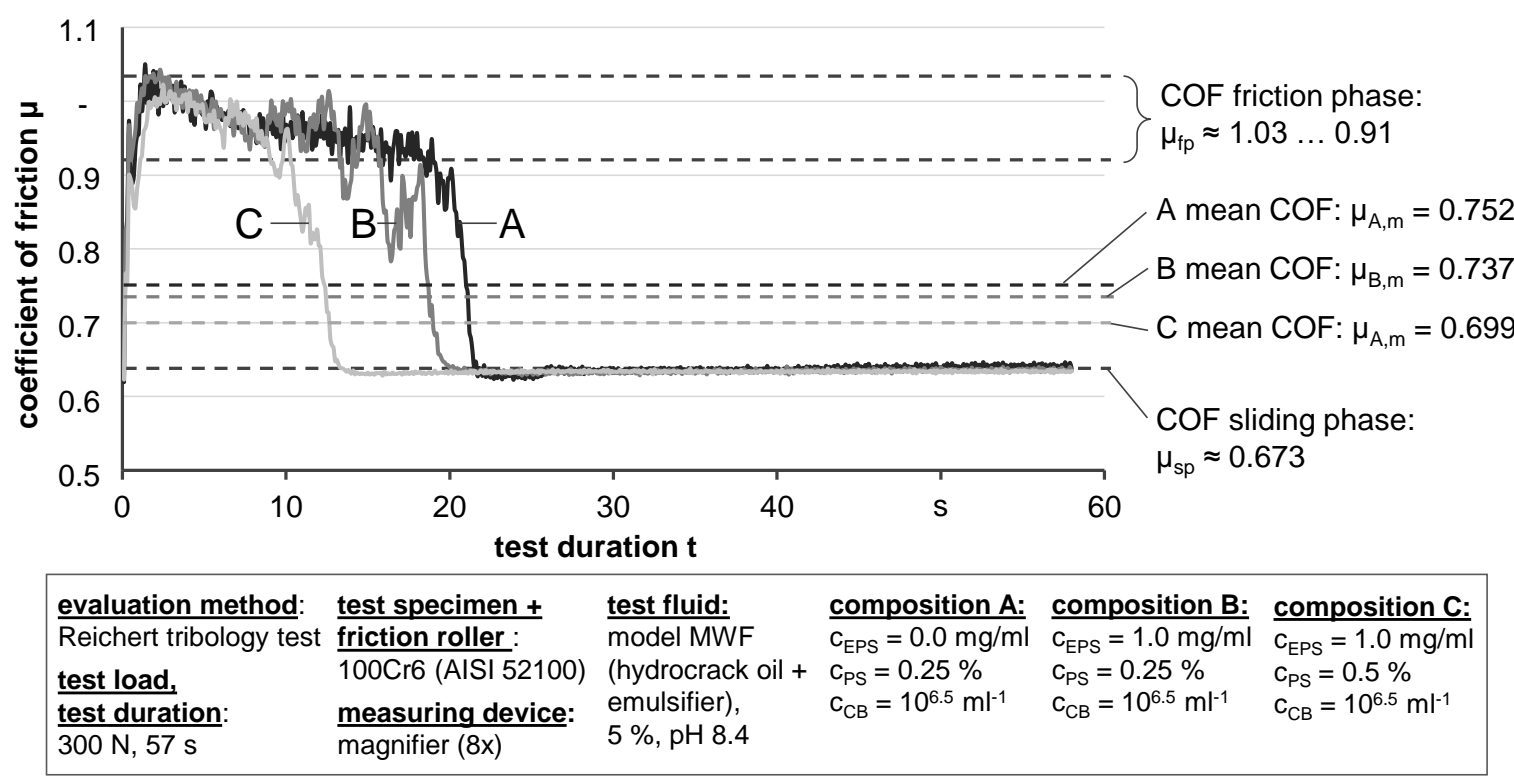

Figure 7. Influence of selected metalworking fluid samples on the coefficient of friction (COF).

\section{Conclusions}

The conducted tribological tests enabled a differentiated evaluation of the influence of aging aspects of water-miscible metalworking fluids on their lubricity. Thereby, selected aspects of aging were combined systematically using design of experiment methods. It was shown that aging aspects could appear that reduced lubricity as well as aspects that caused an increase in lubricity. The decrease of concentration of a wear-reducing additive resulted in a decrease of lubricity. As expected, in contrast, the increase in bacterial cell bodies and the accumulation of EPS led to a significant increase in lubricity. The decrease in the emulsifier concentration, and thus the increase in the average droplet size, had a slightly negative effect on the lubricity as long as the emulsion was not phase separated. Analysis of the interactions between the aspects showed a saturation effect for the combination of high concentrations of the wear-reducing additive and the EPS. The results of the design of experiments enabled the development of an empirical regression model, whereby the influence of the relevant aging aspects could be described in an integrated way for the first time.

Considering these results, it is reasonable why it could be observed in industrial practice, as well as in scientific long-term experiments, that water-miscible metalworking fluids did not show a significant decrease in performance over the duration of use [10,12]. The increase in bacterial cells and the accumulation of lubricating metabolic products can compensate a possible loss of quality through the decomposition of original components of the metalworking fluid.

In further research work, the influence of aging aspects on the performance of metalworking fluids should be evaluated in a manufacturing process. Machining processes (e.g., a grinding process) allow the determination of relevant parameters such as cutting forces, surface roughness, or critical material removal rates. This allows more precise conclusions regarding the performance in the manufacturing process than with the characteristic value of "lubricity" measured in tribological experiments.

Author Contributions: Investigation, B.S.; Project administration, D.M.; Writing—original draft, B.S.; Writing—review \& editing, D.M.

Funding: The authors wish to thank the Deutsche Forschungsgemeinschaft (DFG) for funding the presented work within the project "Artificial aging of water miscible metal working fluids" (reference number ME 4447/4-1).

Conflicts of Interest: The authors declare no conflicts of interest. 


\section{References}

1. Brinksmeier, E.; Meyer, D.; Huesmann-Cordes, A.G.; Herrmann, C. Metalworking fluids-mechanisms and performance. CIRP Ann. Manuf. Technol. 2015, 64, 605-628. [CrossRef]

2. Norm DIN 51385. Schmierstoffe-Bearbeitungsmedien für die Umformung und Zerspanung von Werkstoffen-Begriffe; Beuth Verlag: Berlin, Germany, 2013.

3. Canter, N. Monitoring metalworking fluids. Tribol. Lubr. Technol. 2011, 67, 42-51.

4. Meyer, D.; Wagner, A. Influence of metalworking fluid additives on the thermal conditions in grinding. CIRP Ann. Manuf. Technol. 2016, 65, 313-316. [CrossRef]

5. Van der Gast, C.; Whiteley, A.S.; Lilley, A.K.; Knowles, C.J.; Thompson, I.P. Bacterial community structure and function in a metalworking fluid. Environ. Microbiol. 2003, 5, 453-461. [CrossRef] [PubMed]

6. Lee, M.; Chandler, A.C. A Study of the Nature, Growth and Control of Bacteria in Cutting Compounds. J. Bacteriol. 1941, 41, 373-386. [PubMed]

7. Passmann, F.J. Microbial Problems in Metalworking Fluids. Tribol. Lubr. Technol. 1988, 44, 431-433.

8. Rabenstein, A.; Koch, T.; Remesch, M.; Brinksmeier, E.; Kuever, J. Microbial degradation of water miscible metal working fluids. Int. Biodeterior. Biodegrad. 2009, 63, 1023-1029. [CrossRef]

9. Thompson, I.P.; van der Gast, C.J. The Microbiology of Metal Working Fluids. In Handbook of Hydrocarbons and Lipid Microbiology; Timmis, K.N., Ed.; Springer: Berlin, Germany, 2010; pp. 2369-2376. [CrossRef]

10. Seidel, B.; Meyer, D.; Brinksmeier, E. Aging of Water Miscible Metal Working Fluids. HTM J. Heat Treatm. Mat. 2016, 71, 131-137. [CrossRef]

11. Madanchi, N.; Thiede, S.; Herrmann, C. Functional and environmental evaluation of alternative disinfection methods for cutting fluids. Procedia CIRP 2017, 61, 558-563. [CrossRef]

12. Koch, T. Auswirkungen des mikrobiellen Befalls von wassergemischten Kühlschmierstoffen auf das Zerspanergebnis, Teil 3. HTM J. Heat Treatm. Mat. 2008, 63, 115-132.

13. Grub, A.M.; Finzi, M.B.A.; Ribas, R.M.; Machado, Á.R. Evaluation of the Cutting Forces and Surface Finishing in Turning Process Using Cutting Fluids Contaminated by Microorganisms. Proc. LUBMAT 2014, 25, 6.

14. Seidel, B.; Meyer, D. Influence of artificial aging on the lubricating ability of water miscible metalworking fluids. Prod. Eng. Res. Dev. 2019, 13, 425-435. [CrossRef]

15. Mayer, B. Prozess- und Produktoptimierung mit Hilfe der Statistischen Versuchsmethodik. Ph.D. Thesis, RWTH Aachen, Aachen, Germany, 1997.

16. Sieberts, K.; van Bebber, D.; Hochkirchen, T. Statistische Versuchsplanung-Design of Experiments (DoE); Springer Verlag: Berlin, Germany, 2010. [CrossRef]

17. VKIS. Bestimmung des Druckaufnahmevermögens mit der Reibverschleißwaage nach Reichert. Available online: https://docplayer.org/123353907-Verbraucherkreis-industrieschmierstoffe-bestimmung-desdruckaufnahmevermoegens-mit-der-reibverschleisswaage-nach-reichert.html (accessed on 27 September 2019).

18. Glasse, B.; Assenhaimer, C.; Guardani, R.; Fritsching, U. Analysis of the Stability of Metal Working Fluid Emulsions by Turbidity Spectra. Chem. Eng. Technol. 2013, 36, 1202-1208. [CrossRef]

19. Omoike, A.; Chorover, J. Spectroscopic Study of Extracellular Polymeric Substances from Bacillus subtilis: Aqueous Chemistry and Adsorption Effects. Biomacromolecules 2004, 5, 1219-1230. [CrossRef] [PubMed]

(C) 2019 by the authors. Licensee MDPI, Basel, Switzerland. This article is an open access article distributed under the terms and conditions of the Creative Commons Attribution (CC BY) license (http://creativecommons.org/licenses/by/4.0/). 